\title{
Antropofagia cultural: \\ momento do pensamento crítico latino-americano
}

\section{Cultural anthropophagy: moment of critical Latin American thinking}

\author{
Sebastião Leal Ferreira Vargas Netto ${ }^{1}$
}

\begin{abstract}
Resumo
O objetivo deste artigo é analisar alguns dos principais manifestos e ensaios produzidos pelo intelectual brasileiro Oswald de Andrade e situar sua contribuição para o quadro do pensamento social latino-americano no século XX. A antropofagia cultural oswaldiana, eivada de um pendor utópico característico do ensaísmo latino-americano, representa uma maneira original e crítica da consciência latino-americana de enfrentar o legado civilizacional e cultural eurocêntrico, podendo ser considerada uma precursora dos estudos pós-coloniais e das atuais teorias "descoloniais".
\end{abstract}

Palavras-chave: pensamento latino-americano; ensaísmo; utopia.

\section{Résumé:}

Le but de cet article est d'analyser les manifestes et les essais les plus importants produits par Oswald de Andrade et de situer la contribution de cet intellectuel brésilien à la pensée latino-américaine au XXème siècle. L'anthropophagie culturelle de cet auteur, parsemée d'éclats utopiques, trait caracteristique de l'essayisme en Amérique Latine, représente, de façon originale et critique, la conscience latino-américaine face à l'héritage civilisationnel et culturel eurocentrique, et peut donc être considérée comme précurseuse des études postcoloniales ou même des théories décoloniales actuelles.

Mots-clés: pensée latino-américaine; essayisme; utopie.

Artigo recebido em: 05/07/2014

Artigo aprovado para publicação em: 10/11/2014

Ainda está para ser corretamente avaliado o lugar ocupado pelas ideias do brasileiro Oswald de Andrade (1890-1954) na história do pensamento social latinoamericano. Intelectual de um inquieto e sadio sarcasmo impulsionado pelo que certa vez

\footnotetext{
${ }^{1}$ Professor efetivo de História da América na Universidade Federal do Rio Grande do Norte (UFRN). Pesquisa em andamento: Seleção e análise dos manifestos latino-americanos de século XXI. E-mail: sebastiaovargas@gmail.com.
}

\section{GANPHLAC}

Revista Eletrônica da ANPHLAC, ISSN 1679-1061, Nº. 17, p. 282-303, jul./dez. 2014. http://revista.anphlac.org.br/ 
chamou de "meu fundamental anarquismo" (ANDRADE, 2004, p. 14), Oswald foi um explorador e experimentador radical de ideias: agitação artística, militância política e aventura pessoal se entrelaçam em sua vida para plasmar uma obra multifacetada que frequentou praticamente todos os gêneros literários, fazendo dele um típico representante de intelectual rebelde e múltiplo tão frequente na melhor estirpe da inteligência latino-americana da primeira metade do século $\mathrm{XX} .{ }^{2} \mathrm{~A}$ seguir, refletiremos sobre a contribuição oswaldiana para a construção de um novo imaginário social destinado aos povos ditos "periféricos" (DEVÉS-VALDÉS, 2012) que passaram pela violência matricial do colonialismo, analisando, principalmente, o Manifesto antropófago (1928) e dois de seus principais ensaios: A crise da filosofia messiânica (1950) e A marcha das utopias (1953).

Podemos generalizar que o pensamento social corresponde às reflexões de uma sociedade sobre si mesma. No caso das Américas, e mais especificamente da América Latina, um componente basilar do esforço por autoconsciência, historicamente, esteve influenciado pelo que Frank Manuel (1984, p. 13) denominou de propensão utópica. Naturalmente, a própria noção de América Latina - um dos objetivos centrais desse próprio esforço conceitual - não poderá ser suficientemente problematizada em um artigo dessa natureza e extensão. É necessário, no entanto, pontuar que entendemos a América Latina como uma realidade composta de muitas diversidades, um mosaico de múltiplas realidades que pode ser analisado e explicado a partir das grandes problemáticas que as englobem, devolvendo a diversidade à unidade (ANSALDI, 2012, p. 25). O quadro do pensamento social nas Américas ficaria incompleto e sensivelmente empobrecido se estivessem ausentes as contribuições de autores que geralmente são apenas alocados no terreno das artes ou da literatura. Talvez seja esse o caso em relação ao pensamento de Oswald de Andrade, comumente reduzido a um momento das manifestações experimentais das vanguardas literárias das primeiras décadas do século XX (mesmo como expressão das melhores delas), ${ }^{3}$ obliterando o formidável potencial

\footnotetext{
${ }^{2}$ Um excelente estudo sobre a história das ideias e dos intelectuais latino-americanos do período é realizada por Richard Morse (2011).

${ }^{3}$ O crítico Jorge Schwartz $(2013$, p. 33) considera a antropofagia oswaldiana "a revolução estéticoideológica mais original das vanguardas latino-americanas daquela época”.
} 
criativo de sua imaginação teórica que alia, aos rigores da erudição, doses saudáveis de humor e poesia, infelizmente tão alheias à teoria social corrente.

\section{Antropofagia como crítica da colonialidade do saber}

A tentação pela busca de precursores ou as polêmicas em torno das influências na história, que Marc Bloch alertava como o "ídolo das origens", podem levar a anacronismos e teleologismos. Conscientes, no entanto, dos perigos emanados pelas sombras desse "ídolo", consideramos que as formulações irreverentes e profundamente criativas da antropofagia oswaldiana podem ser encaradas como uma prefiguração do projeto pós-colonial de "provincializar o Ocidente" (CASTRO-GÓMEZ, 2007); uma contribuição estimulante para a produção de um "contradiscurso" sobre a modernidade e um ataque ao que o pensador argentino Walter Mignolo (2005) define como a "hegemonia epistêmica" ocidental. São ideias e intuições que possuem, como característica mais saliente, a tentativa de libertação do espelho eurocêntrico (onde a imagem das sociedades latino-americanas tem sido historicamente distorcida) por um ataque ao que o pensador peruano Aníbal Quijano (2005) denominou como “colonialidade do saber”. Um formidável exemplo desse enfoque analítico é a coletânea de textos organizada por João Cezar de Castro Rocha (2011), que, vista em seu conjunto fundamental, caracteriza a antropofagia cultural como uma narrativa alternativa extremamente poderosa para se pensar a opção descolonial. ${ }^{4}$ Outro exemplo de análise da antropofagia literária como contradiscurso anticolonial (além de suas complexas conexões com a antropofagia ritual de certos povos ameríndios) são as considerações do antropólogo Carlos Fausto (2001, p. 21):

Minhas simpatias estão, antes, com os modernistas antropófagos.
Identifico nesse momento da cultura nacional um poderoso
contradiscurso às continuidades coloniais. A antropofagia literária
capturou o sentido profundo da antropofagia literal, que é o da
constituição de sujeitos (múltiplos) por meio da apropriação violenta
de princípios de subjetivação, que são, por necessidade, exteriores. O
Canibal busca mobilizar a perspectiva do outro em proveito da
reprodução de si, exprimindo a contradição entre um desejo

${ }^{4}$ Uma discussão interessante sobre a "opção descolonial” encontra-se na obra de Mario Yupi (2006).

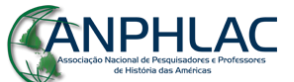

Revista Eletrônica da ANPHLAC, ISSN 1679-1061, Nº. 17, p. 282-303, jul./dez. 2014. http://revista.anphlac.org.br/ 
centrífugo, heteronômico, e uma necessidade de autoconstituição enquanto sujeito. Esse é o sentido da metáfora antropofágica modernista, que se ergueu, como eles diziam, contra o decalque romântico dos índios, contra o índio catequizado, filho de Maria, irmão do santíssimo. Ao transformar o estigma em valor, os modernistas desorganizaram um modo discursivo tão colonialmente ordinário.

A visão antropofágica, intuída inicialmente por Oswald, deve ser considerada justamente a partir de seu engajamento aberto e direto com uma outra narrativa possível da modernidade. Uma narrativa com potencial crítico enorme - mas não ausente de contradições e esperanças que se revelaram inocentes - que embaralha propositalmente as hierarquias embutidas em conceitos como centro e periferia, metrópole e colônia, civilização e selvageria, fundamentando, na opinião de David Jackson (2011, p. 435), a inclusão do nome de Oswald na mesma constelação teórica que, "na história do póscolonialismo, inclui figuras como Rushie, Gandhi, Senghor, Bandaranaike e Octavio Paz".

No artigo Uma adesão que não queremos, publicado na Revista de Antropofagia em 12 de junho de 1929, Oswald de Andrade escreveu, sob o pseudônimo de Poronominare (entidade divina do amor em certas cosmogonias indígenas):

\begin{abstract}
Antropofagia é simplesmente a ida (não o regresso) ao homem natural, anunciada por todas as correntes da cultura contemporânea e garantida pela emoção muscular de uma época maravilhosa - a nossa! O homem natural que nós queremos pode tranquilamente ser branco, andar de casaca e de avião. Como também pode ser preto e até índio. Por isso o chamamos de "antropófago" e não tolamente de "tupi" ou "pareci".
\end{abstract}

Seguindo David Jackson (2011), o problema do intelectual entre culturas (que, segundo ele, muitas vezes inventa e se converte num "outro outro") é tentar combater e corrigir o Ocidente e, no mesmo gesto, defender valores de sua localidade, sejam o instinto, o vitalismo, a resistência ou a deglutição: "Entre eles, Oswald talvez não seja o mais original, mas com certeza é o mais divertido" (JACKSON, 2011, p. 435). Podemos sugerir que as intuições antropofágicas de Oswald afirmam a simultaneidade dos diferentes lugares na conformação do mundo: abrem espaço para que múltiplas epistemes dialoguem. Em nuestra América, mais que hibridismos, há que se reconhecer

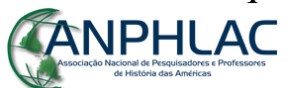

Revista Eletrônica da ANPHLAC, ISSN 1679-1061, Nº. 17, p. 282-303, jul./dez. 2014. http://revista.anphlac.org.br/ 
que há pensamentos que aprenderam a viver entre lógicas distintas, a se mover entre diferentes códigos e, por isso, mais que para multiculturalismo, sinaliza para interculturalidades, para gnoses liminares, para diálogo de saberes (LANDER, 2005). As formulações de Oswald também podem ser lidas como um importante momento no processo de autonomização e emancipação cultural, do esforço por refletir sobre o que Simón Bolívar chamou de "pequeno gênero humano", que são as sociedades latinoamericanas. Seu pensamento deve ser inscrito no que é definido por pensamento crítico, pois é um dos momentos da consciência social latino-americana que respalda uma vontade de mudança social, que estimula a crítica radical da ordem constituída, abrindo possibilidades para uma superação das relações de subalternidades existentes (FERNÁNDEZ RETAMAR, 2006). Suas ideias estão permanentemente perpassadas pelo signo de uma dialética utópico-revolucionária entre um passado não somente précapitalista, mas pré-patriarcal, e um futuro não somente socialista, mas "matriarcal" (expressão que, como veremos, deve ser compreendida como mito e símbolo de uma sociedade libertária).

No conjunto de ensaios publicados em 1953 e, posteriormente, reunidos em volume sob o título de A marcha das utopias, Oswald de Andrade (1990, p. 204) define utopia como "o fenômeno social que faz marchar para frente a própria sociedade. [...] No fundo de cada Utopia não há somente um sonho, há também um protesto”. Conformando a utopia antropofágica, podemos identificar duas pulsações que se entrelaçam em operações teóricas distintas: a primeira tem a ver com o mistério, isto é, o que ainda não está desvendado, o futuro, a esperança, o sentimento órfico, a ansiedade infinita para além... A outra é relativa a uma rigorosa e seletiva reinterpretação da "tradição histórica" brasileira, entendida como uma soma dos momentos supremos, das realizações mais expressivas, dos anseios mais profundos do passado de um povo, que poderiam indicar a conformação de um projeto utópico. Exemplos desse esforço reinterpretativo podem ser observados quando Oswald afirma, no mesmo ensaio, que os "pontos altos do Ciclo das Utopias foram: no século XVI, a miscigenação trazida pelas descobertas; no século XVII, a nossa luta nacional contra a Holanda" (1990, p. 162); ou quando ele inicia a nova fase histórica "antropofágica" no ano em que o primeiro bispo do Brasil, Pero Fernandes Sardinha, após naufragar no litoral de Alagoas, foi morto e

\section{GANPHLAC}

Revista Eletrônica da ANPHLAC, ISSN 1679-1061, Nº. 17, p. 282-303, jul./dez. 2014. http://revista.anphlac.org.br/ 
devorado pelos índios caetés. O Manifesto antropófago sintomaticamente é datado: "Em Piratininga. Ano 374 da Deglutição do Bispo Sardinha” (ANDRADE, 1990, p. 52). Richard Morse (2011), ao analisar a vida e obra de Oswald, "iconoclasta, rabelaisiano, eterno viajante", afirma que

\begin{abstract}
Seus poemas e manifestos abordam vários temas históricos: o sistema Igreja-Estado que moldou a civilização brasileira, a sociedade patriarcal e seus padrões morais, os sonhos messiânicos, a retórica dos intelectuais eurófilos, um indianismo que mascarou a concepção do colonizado e as frustações do colonizado. Oswald não só inspirou, depois de morto, a internacionalmente conhecida Tropicália brasileira da década de 1960, como também antecipou os motivos que iriam, ao mesmo tempo, atrair historiadores acadêmicos (MORSE, 2011, p. 41$42)$.
\end{abstract}

Revitalizando a perspectiva primitivista, tão cara às vanguardas estéticas das duas primeiras décadas do século $\mathrm{XX}$, e se apropriando metaforicamente da antropofagia indígena e do sentimento órfico inerente ao pensamento selvagem (mas não somente a ele), a antropofagia cultural de Oswald deve ser compreendida à luz de uma forte perspectiva utópica.

\title{
Manifesto e ensaio: instrumentos do pensamento utópico
}

Os manifestos são um tipo de expressão literária que constituem um acervo documental essencial sobre a natureza e o conteúdo do pensamento social e cultural latino-americano. Podemos definir o manifesto como um texto que expõe ideias (políticas, artísticas etc.) e que conclama à emergência de uma corrente que as sustente (ADELINE, 2013, p. 60). Se de algum modo fosse possível uma visão do seu conjunto, teríamos um formidável panorama condensado das ideias políticas, sociais e culturais que agitaram (ou tentaram agitar) as sociedades, sobretudo no século XX. Curiosamente pouco teorizados, tanto por historiadores quanto por críticos literários ou sociólogos (que geralmente contentam-se em realizar antologias ${ }^{5}$ ), os manifestos são veículos

\footnotetext{
5 A melhor delas, em relação aos manifestos das vanguardas literárias latino-americanas, é a de Jorge Schwartz (2008); uma antologia específica dos manifestos e documentos revolucionários da região foi organizada por Michael Löwy (1999).
}

\section{GANPHLAC}

Revista Eletrônica da ANPHLAC, ISSN 1679-1061, Nº 17, p. 282-303, jul./dez. 2014. http://revista.anphlac.org.br/ 
privilegiados de crítica social e contêm um considerável elemento de utopismo (KROTZ, 1988).

A relação entre arte radical e política revolucionária foi uma questão crucial para a intelectualidade latino-americana do período entre guerras (ADES, 1997, p. 125). Os diferentes grupos e movimentos que formavam a avant-garde, assim como suas contrapartidas na Europa, se davam a conhecer através de manifestos, revistas, exposições e conferências. Entre as revistas, as mais significativas foram: Amauta (1926), no Peru; Martín Fierro (1924), em Buenos Aires; Actual e El Machete (1924), no México; e Klaxon (1922) e a Revista de Antropofagia (1928) em São Paulo (BELLUZZO, 1990). A Revista de Antropofagia, coeditada por Oswald de Andrade, Alcântara Machado e Raul Bopp, certamente apropriou-se de alguns princípios das vanguardas europeias (futurismo e dadaísmo), mas estava muito longe de ser uma mera imitação. Em 1920, Francis Picabia chegara a publicar, em Paris, um Manifeste Cannibale e fundara, com Tristan Tzara, a revista Cannibale (SUBIRATS, 2011). Mas enquanto os franceses utilizavam o termo "canibal" como provocação, os modernistas brasileiros transformavam o ritual dos tupis (os "brasileiros originais") de ingestão da força e poder dos inimigos em processo de apropriação das propriedades nutritivas da cultura europeia. Em 1928, Oswald de Andrade publicou o célebre Manifesto Antropófago (quatro anos antes - no mesmo ano da publicação do Manifesto Surrealista em Paris - ele já havia publicado o Manifesto da Poesia Pau-Brasil), iniciando uma influente revolução no mecanismo de funcionamento da cultura brasileira, deslocando transgressivamente a noção de identidade que, a partir dali, se construiria no ato de devoração do outro: "Só me interessa o que não é meu. Lei do homem. Lei do antropófago". 6 Alguns modernistas brasileiros da década de 1920, apesar do limitado conhecimento antropológico de então e numa enigmática e chocante intuição, que as pesquisas da melhor antropologia atual estão complexificando, fizeram do motivo da antropofagia ritual indígena a base de uma filosofia e estética insurgente. Assim como

\footnotetext{
6 "Lei do antropólogo", agregaria o brilhante antropólogo brasileiro Eduardo Viveiros de Castro (2007, 118), formulador do conceito do perspectivismo indígena que considera "um conceito da mesma família política e poética que a antropofagia de Oswald de Andrade, isto é, como uma arma de combate contra a sujeição cultural da América Latina, índios e não índios confundidos, aos paradigmas europeus e cristãos. O perspectivismo é a retomada da antropofagia oswaldiana em novos termos".
}

\section{GANPHLAC}

Revista Eletrônica da ANPHLAC, ISSN 1679-1061, Nº. 17, p. 282-303, jul./dez. 2014. http://revista.anphlac.org.br/ 
os índios tupinambás devoravam seus inimigos para se apropriar de sua força, os modernistas insistiam que a missão do intelectual no Brasil seria a de capturar, cozinhar e digerir os vários tipos de produtos culturais importados (técnicas, filosofias, artes, políticas etc.) para, metabolizando sua positividade e expelindo suas fraquezas, os transformarem permanentemente em novas sínteses. Estas, corretamente exploradas, teriam a missão de voltar a cultura imposta, agora devidamente transformada, contra o colonizador. Obviamente, os antropófagos exigiam uma "desvespucização" das Américas e uma "descabralização" do Brasil. Na segunda "dentição" da Revista de Antropofagia, de 24 de abril de 1929, Oswald lamentava, com o curioso pseudônimo de Marxillar (Marx + maxilar), que os brasileiros continuassem a ser escravos de uma cultura europeia decadente e denunciava a "mentalidade colonial" ainda imperante, ameaçando: "Então chegou a vez da descida antropofágica. Vamos comer tudo de novo". Na síntese de Ella Shoat e Robert Stam (2006, p. 428),

\begin{abstract}
A noção de antropofagia assume a inevitabilidade das trocas culturais entre "centro" e "periferia" e a consequente impossibilidade de qualquer retorno nostálgico a uma pureza original. Como é impossível haver uma recuperação não problemática das origens nacionais, livres das impurezas das influências externas, o artista na cultura dominada não deveria ignorar a presença estrangeira, mas engoli-la, carnavalizála, reciclá-la para fins nacionais, sempre de uma posição de autoconfiança cultural". [...] A metáfora do canibalismo foi explorada pelos modernistas brasileiros de perspectivas positivas e negativas. $\mathrm{O}$ lado negativo utilizava o canibalismo para revelar o caráter perverso do darwinismo social da sociedade de classes. Mas o lado positivo era ainda mais sugestivo: ao radicalizar a valorização iluminista da liberdade do nativo indígena, os modernistas enfatizavam a organização matriarcal e comunitária dos índios como modelos utópicos.
\end{abstract}

A estrutura básica dos manifestos pode ser resumida nos seguintes pontos: 1) quem somos; 2) como entendemos e/ou criticamos tal aspecto da realidade social; 3) o que pretendemos; 4) como tentaremos realizar o que pretendemos. Outra característica: por estarem destinados a impressionar e orientar a opinião pública, a linguagem de cada manifesto tende a ser forte, concisa e sensacional. Os manifestos das vanguardas literárias americanas, segundo o poeta e ensaísta cubano Roberto Fernández Retamar (2011, p. 326), converteram-se em gênero literário pelo "seu caráter programático, seu

\title{
GANPHLAC
}

Revista Eletrônica da ANPHLAC, ISSN 1679-1061, Nº. 17, p. 282-303, jul./dez. 2014. http://revista.anphlac.org.br/ 
inevitável esquematismo, a faiscação das propostas que lhes davam um involuntário, mas evidente ar comum". O autor cubano considera que os manifestos de Oswald de Andrade se acham entre os mais valiosos das vanguardas latino-americanas (e também de outras), e estabelece uma comparação:

Tanto a antropofagia como meu "Caliban" se propunham a reivindicar e esgrimir como símbolos válidos um lado de nossa América que a história oficial havia denegrido. Ambos reclamavam o direito que nos assiste não só de nos incorporarmos ao mundo, mas de nos apropriarmos do mundo, de acordo com as características que nos são próprias. Ambos são obras de poetas, que se valem livremente de imagens (FERNÁNDEZ RETAMAR, 2011, p. 327).

É muito difícil tentar resumir tais escritos, eles mesmos sendo resumos ou compêndios telegráficos que, com considerável ímpeto iconoclasta e dose de ironia, lirismo e humor, realizavam uma revisão da história brasileira, uma reivindicação de um passado e de uma visão de mundo que deveriam ser recuperados com vistas à construção de uma cultura realmente criadora e liberta do peso do passado de subalternidade colonial (inclusive, ou sobretudo, da colonialidade mental).

Seguindo o esquema proposto acima, selecionamos algumas frases retiradas do Manifesto antropófago de 1928:

1) Quem fomos e somos: Tupy or not tupy, that is the question. Filhos do sol, mãe dos viventes. Já tínhamos o comunismo. Já tínhamos a língua surrealista. Sem nós a Europa não teria sequer a sua pobre declaração dos direitos do homem. Encontrados e amados ferozmente, com toda a hipocrisia da saudade, pelos imigrados, pelos traficados e pelos touristes. Preguiçosos no mapa-múndi do Brasil. Tínhamos a justiça, codificação da vingança. Fizemos foi Carnaval. O contato com o Brasil Caraíba. Montaigne. O homem natural. Rousseau.

2) Se manifesta explicitamente contra: o Padre Vieira; a mãe dos Gracos; as elites vegetais; os importadores de consciência enlatada; as histórias do homem que começam no Cabo Finisterra; as sublimações antagônicas; as escleroses urbanas; os conservatórios e o tédio especulativo; todas as catequeses; importadores de consciência enlatada; a realidade social, vestida e opressora; Goethe; a Corte de D. João VI; Anchieta; os maridos suspeitosos postos em drama.

3) O que pretende: A ciência codificação da Magia. Antropofagia. Queremos a Revolução Caraíba. Maior que a Revolução Francesa. A unificação de todas as revoltas eficazes na direção do homem. A idade de ouro anunciada pela América. E todas as girls. A realidade sem

\section{GANPHLAC}

Revista Eletrônica da ANPHLAC, ISSN 1679-1061, Nº. 17, p. 282-303, jul./dez. 2014. http://revista.anphlac.org.br/ 
complexos, sem loucura, sem prostituições e sem penitenciárias do matriarcado.

4) Como tentarão (os antropófagos) realizar o que pretendem: Só podemos atender ao mundo oracular. A existência palpável da vida. A transformação do Tabu em Totem. Pelos roteiros. Acreditar nos sinais, acreditar nos instrumentos e nas estrelas. As migrações. A fuga dos estados tediosos. A magia e a vida. Alegria é a prova dos nove. Da Revolução Francesa ao Romantismo, à Revolução Bolchevique, à Revolução surrealista e ao bárbaro tecnizado de Keyserling. Caminhamos.

Ao analisar o Manifesto antropófago, David Jackson (2011), na esteira do historiador Richard Morse (1990), caracteriza seu discurso como uma relação entre forças importadas e exportadas. No primeiro caso: caravelas, catequese, rubricas, César, Napoleão, casamento, catolicismo, roupas, penitenciárias, gramáticas, coleções vegetais, fronteiras, consciência enlatada, lógica, empréstimos, lábia, religiões de meridiano, elites, determinismos, histórias, sublimações, loucura, prostituição, missionários, especulações, conservatórios, complexos, autoridades, patriarcado, jesuítas, colonos, Goethe, descobrimento do Brasil... Na lista dos valores poéticos-filosóficos "exportáveis" ou "renovados pela energia adquirida pelo inimigo deglutido" (no caso, a civilização ocidental) estariam: antropofagia, a revolução Caraíba, unificação, preguiça, participação, vacina, tótens, instinto, comunicação com o solo, carnaval, magia, vingança, distribuição de bens, o mundo não datado, adivinhação, migrações, a fuga do tédio, felicidade, girls, o matriarcado, a experiência pessoal, roteiros, absorção, transformação e alegria.

O historiador John Skirius (1997, p. 9) define o gênero ensaístico do seguinte modo: "meditação escrita em estilo literário; é a literatura de ideias e, geralmente, leva a marca pessoal do autor. É prosa, mas não é ficção". Seriam características do ensaio a extensão relativamente breve, a qualidade literária, certa propensão para confessar, divagar ou exprimir ideias com intuito em convencer. Segundo Skirius, o ensaio estaria em oposição (mas sem uma fronteira claramente discernível) à produção acadêmica ou científica; aos tratados filosóficos ou sociológicos; às produções jornalísticas; aos contos e novelas e aos discursos e manifestos políticos. O ensaio combinaria elementos (em variadas proporções) de todos esses gêneros literários, não por acaso sendo definido

\section{GANPHLAC}

Revista Eletrônica da ANPHLAC, ISSN 1679-1061, Nº. 17, p. 282-303, jul./dez. 2014. http://revista.anphlac.org.br/ 
pelo mexicano Afonso Reyes como o "centauro dos gêneros literários" (SKIRIUS, 1997, p. 10).

Talvez pela sua característica de gênero literário híbrido por excelência, o ensaio foi um veículo privilegiado de propagação de ideias e pensamentos utópicos tão caros à tradição do pensamento social latino-americano. Para ficarmos somente na geração de Oswald (1890-1954), poderíamos citar autores que, com diversas perspectivas ideológicas, refletiram explicitamente sobre a temática das utopias: os mexicanos José Vasconcelos (1882-1959) e Alfonso Reyes (1889-1959); o dominicano Pedro Henríquez Ureña (1884-1946); e o peruano José Carlos Mariátegui (1894-1930).

No vasto e pouco definido universo do discurso utópico, a América ocupou lugar de destaque. Pode-se dizer que as relações da América com as tradições utópicas ocidentais são originárias e permanentes: desde as tentativas de Vasco de Quiroga até os atuais projetos dos zapatistas de Chiapas; das propostas do sumak quaysai andino ao Socialismo Bolivariano, ${ }^{7}$ passando por personagens e experiências das mais diversas, a América, em sua dimensão concreta ou imaginária, tem sido o cenário de enormes pulsões utópicas (mas também, desgraçadamente, o território da distopia da violência e exploração colonial e capitalista). A história do pensamento americano é perpassada por um poderoso impulso utópico, num processo que ainda está longe do esgotamento. No ensaio A marcha das utopias, Oswald (1990, p. 164) escreve:

\begin{abstract}
A geografia das Utopias situa-se na América. É um nauta português que descreve para Morus a gente, os costumes descobertos do outro lado da terra. Um século depois, Campanella, na Cidade do Sol, se reportaria a um armador genovês, lembrando Cristóvão Colombo. E mesmo Francisco Bacon (possivelmente Shakespeare), que escrevia $A$ Nova Atlântida em pleno século XVII, faz partir a sua expedição do Peru. A não ser A República de Platão, que é um estado inventado, todas as Utopias, que vinte séculos depois apontam no horizonte do mundo moderno e profundamente o impressionaram, são geradas da descoberta da América. O Brasil não fez má figura nas conquistas sociais do Renascimento.
\end{abstract}

Não é casual que o gênero utópico floresça a partir do impacto, no imaginário europeu, da descoberta do Novo Mundo: "Sem nós a Europa não teria sequer a sua

\footnotetext{
${ }^{7}$ Uma análise lúcida dessas propostas encontra-se na obra do sociólogo argentino Atílio Boron (2010).

\section{GANPHLAC}

Revista Eletrônica da ANPHLAC, ISSN 1679-1061, Nº. 17, p. 282-303, jul./dez. 2014. http://revista.anphlac.org.br/
} 
pobre declaração de direitos do homem", afirmava o Manifesto antropófago. Na medida em que esse novo horizonte geográfico permite a reativação de todo o rico manancial mítico clássico (Atlântida, Paraíso Perdido, Ilhas da Felicidade ou Hy Bressail, Arcádia, El Dorado), ele opera uma importante alteração que caracterizará essencialmente a utopia moderna: a projeção para o futuro e a crítica do presente. O escritor cubano Alejo Carpentier, em um pequeno ensaio escrito em 1948, O último buscador do Eldorado, refletia sobre a temática com as seguintes palavras:

Os homens da Europa perseguiram durante séculos, aliando estranhamente o propósito de saquear o ouro de Manoa ao desejo de encontrar uma Utopia, uma Heliópolis, uma Nova Atlântida, uma Icária, onde os homens fossem menos loucos, menos cobiçosos, vivendo uma história que não tivesse começado com o pé esquerdo. Era na América que Thomas More situava sua Utopia: também na América devia encontrar-se a Cidade do Sol de Campanella. Foi de fato na América que Etienne Cabet fundou sua malfadada Icária. [...] $\mathrm{Na}$ grande aventura de solidão, de risco, de vontade que implica a condição de navegantes da selva, alguns desses homens superaram em si mesmos a etapa espúria da sede de riqueza obtida sem esforço, para encontrar sua própria e íntima Utopia. A Utopia tangível nas obras, sensível nas lembranças, de uma vida realizada, de um destino ímpar, de uma existência afirmada em feitos, de um completo desprezo pelas inconsistentes facilidades da chamada civilização (CARPENTIER, 2006, p. 41).

O mexicano Alfonso Reyes considerava que antes de se deixar sentir por sua presença, América (como símbolo da Utopia) se deixava sentir por sua ausência: "Nuestra América debe vivir como si se preparase siempre a realizar el sueño de la utopía, de la república feliz, que prestaba singular calor a las páginas de Montaigne, cuando se acercaba a contemplar las sorpresas y las maravillas del nuevo mundo" (REYES, 1956, p. 87).

O argentino Carlos Piñero Iñíguez (2006, p. 88) nota que reflexões como a de Oswald, Carpentier e Reyes evidenciam a matriz eurocêntrica de muitas de nossas ideias, pois a relação histórica da América com a utopia seria a de fornecer um espaço aos melhores sonhos dos europeus; um lugar que se prestaria à projeção de sonhos de criação de uma nova sociedade que, no Velho Mundo, já pareciam impossíveis de serem concretizados. Assim como o Novo Mundo inspira a obra que marca o nascimento

\section{GANPHLAC}

Revista Eletrônica da ANPHLAC, ISSN 1679-1061, Nº. 17, p. 282-303, jul./dez. 2014. http://revista.anphlac.org.br/ 
oficial do subgênero literário da novela utópica, com a obra de Thomas Morus de 1516, também o "pai” do ensaio moderno, Montaigne, evoca um marinheiro francês envolvido na exploração do litoral brasileiro. No seu ensaio Dos canibais, Montaigne ouviria de um marinheiro francês o relato sobre o modo de vida espontâneo, a mansidão e pureza dos índios, dando origem à figura filosófica radical do "bom selvagem", a qual, quando incorporada por Rousseau, teria as conhecidas e explosivas consequências sobre o pensamento do Iluminismo, o movimento Romântico e a fase mais radical da Revolução Francesa, 1848 e as posteriores alternativas socialistas (ABRAMSON, 1999; CLAEYS, 2013).

\section{A filosofia antropofágica: insigths e afinidades}

Se no ensaio A marcha das utopias, Oswald revisa os momentos culminantes do pensamento utópico e de um humanismo subversivo, identificando-os com os avanços da aventura humana, é no ensaio A crise da filosofia messiânica, publicado em $1950,{ }^{8}$ que ele desenvolve as ideias sobre a antropofagia intuídas no Manifesto antropófago da década de 1920. A partir de elaborações sobre as culturas indígenas brasileiras (que representariam um testemunho de uma cosmovisão mais ampla e diversificada que, remotamente, abrangeria muitos povos e culturas), Oswald forjou uma metáfora de modelo social baseado no ócio e, principalmente, na recusa radical da autoridade (Estado). Recusando conscientemente a dialética hegeliana "do senhor e do escravo" comendo ritualmente o "outro-inimigo" ao invés de escravizá-lo e explorá-lo -, algumas sociedades "primitivas" teriam impedido o desenvolvimento de toda uma economia política e sua correspondente espiritualidade, as quais levariam à conformação de sociedades baseadas na propriedade privada, na exploração do trabalho, na divisão de classes e raças, no exclusivismo religioso e no imperialismo. Oswald analisa a história da humanidade sob o ponto de vista do utópico esforço de conquista do ócio e suas relações dialéticas com as forças de sua negação: o "neg-ócio", o trabalho, a escravidão, o colonialismo, o capitalismo e suas justificativas ideológicas e religiosas (por ele chamado de filosofia messiânica). Em resumo: o mundo se dividiria, em sua longa

\footnotetext{
${ }^{8}$ Sobre o episódio, ver a obra de Maria Augusta Fonseca (2007, p. 302). 
história, em estruturas sociais e componentes culturais conceitualizados metaforicamente como "matriarcado" e "patriarcado"; em correspondência com esses hemisférios antagônicos existiriam, de um lado, uma cultura antropofágica e, de outro, uma cultura messiânica, a qual estaria, dialeticamente, sendo substituída pela primeira, como síntese ou terceira via, fortalecida pelas conquistas técnicas. Vale dizer: só a restauração tecnificada de uma cultura antropofágica poderia resolver os problemas atuais do homem e da filosofia: " 10 termo: tese - o homem natural. 2 o termo: antítese o homem civilizado. 3으 termo: síntese - o homem natural tecnizado". (ANDRADE, 1990, p. 103)

Com suas ideias, Oswald queria contribuir para o desenvolvimento de uma subjetividade rebelde que respaldaria as escolhas e embates societários que devem acompanhar a luta pela realização das imensas possibilidades e potencialidades criadas pela civilização atual, todavia ainda amplamente hegemonizadas pela lógica dominadora e alienante do capitalismo-patriarcado dominante. Oswald formulou uma filosofia de avanço da sociedade pelo retorno de um "matriarcado" potencializado pelas conquistas técnicas, que deveriam ter seus usos reorientados pelo "reencantamento" de uma cultura revitalizada pelas contribuições da "mente primitiva".

Nas formulações contidas no ensaio de 1950 se mesclam e acabam por se confundir, segundo o sólido estudo de Benedito Nunes (1979, p. 66), duas linhas diferenciadas de pensamento: uma crítico-histórica (tributária de Hegel, Marx, Weber, Mannheim) e outra de caráter mítico, tributária do pensamento de Nietzsche e sua

Filosofia trágica, que incorpora a psicologia orgiástica integrante dos ritos de sacrifício, ligados às matrizes primordiais das relações religiosas entre o homem e o universo. O homem da cultura antropofágica, assumindo a dureza de Zaratustra, afirma dionisiacamente a sua vontade de poder; "devorando" o que há de trágico na existência, transforma todos os tabus em totens, isto é, em valores humanos e obras de arte (NUNES, 1979, p. 67).

A chave para encontrar o justo valor do ensaio filosófico do nosso poeta antropófago estaria, portanto, na feliz associação entre pensamento mítico e pensamento crítico. É como mito moderno, no sentido preciso que lhe confere José Carlos

\section{GANPHLAC}

Revista Eletrônica da ANPHLAC, ISSN 1679-1061, Nº. 17, p. 282-303, jul./dez. 2014. http://revista.anphlac.org.br/ 
Mariátegui, ${ }^{9}$ que devemos entender tanto o matriarcado tecnizado quanto a cultura antropofágica, inseridos em um horizonte utópico e dotados de um sentido de visão de mundo universal, numa perspectiva não só histórica, mas também psicologista, existencial e estética. O poder do símbolo-mito-utopia do matriarcado tecnizado e da cultura antropofágica oswaldiana tem o potencial de antecipar e prefigurar uma vasta gama de propostas e formulações sociológicas, artísticas e filosóficas, todas de matriz libertária, posteriores à sua obra.

Poderíamos elencar sumariamente, temerosos dos perigos das simplificações e carentes de espaço para matizar suficientemente as considerações, as "afinidades eletivas" - na acepção proposta por Michael Löwy ${ }^{10}$ (1989) - entre as ideias de Oswald de Andrade (e seus usos posteriores) com uma série de autores e correntes de pensamento:

1) A crítica ao patriarcado e suas formas de opressão sociais, culturais e religiosas; às opressões de gênero; à família nuclear; um elogio da libertação sexual e dos costumes; uma crítica aos supostos aspectos universais do freudismo.

2) A contribuição da cosmovisão das sociedades ditas "primitivas" e do pensamento indígena para a emergência de novas culturas políticas com maior densidade/radicalidade democrática e comunitária (DÁVALOS, 2005).

3) A oposição oswaldiana entre os dois hemisférios culturais e históricos do "matriarcado" e "patriarcado" (este último concebido como uma tríade EstadoPatriarcado-Messianismo) prefigurando as teses da antropologia política de Pierre Clastres (1978) e suas "sociedades contra o Estado"; as óbvias analogias entre a

\footnotetext{
${ }^{9}$ Numa série de artigos escritos entre 1924 e 1925, especialmente A imaginação e o progresso; Duas concepções da vida; $O$ homem e o mito e A luta final, Mariátegui teoriza sobre o conceito de utopia e a "peremptória necessidade de uma fé e de um mito que levem os homens a viver perigosamente. [...] $\mathrm{O}$ mito move o homem na história. Sem um mito, a existência do homem não tem nenhum sentido histórico. Quem faz a história são os homens possuídos e iluminados por uma crença superior, por uma esperança sobre-humana". (MARIÁTEGUI, 2005, p. 55-57)

10 "Designamos por 'afinidade eletiva' um tipo muito particular de relação dialética que se estabelece entre duas configurações sociais ou culturais, não redutível à determinação causal direta ou à influência no sentido tradicional. Trata-se, a partir de uma certa analogia estrutural, de um movimento de convergência, de atração recíproca, de confluência ativa, de combinação capaz de chegar até a fusão. Em nossa opinião, seria interessante tentar fundar o estatuto metodológico desse conceito, como instrumento de pesquisa interdisciplinar que permita enriquecer, nuançar e tornar mais dinâmica a análise das relações entre fenômenos econômicos, políticos, religiosos e culturais". (LÖWY, 1989, p. 13)
}

\section{GANPHLAC}

Revista Eletrônica da ANPHLAC, ISSN 1679-1061, Nº. 17, p. 282-303, jul./dez. 2014. http://revista.anphlac.org.br/ 
antropofagia filosófica de Oswald e as atuais pesquisas antropológicas do perspectivismo ameríndio de Eduardo Viveiros de Castro (2002) e Carlos Fausto (2001).

4) A reflexão central sobre peso da experiência colonial nas sociedades americanas e seus duradouros reflexos sociais, culturais e políticos (pós-colonialidade) e a necessidade de realizar um esforço de autoconsciência crítico e "antropofágico" sobre a identidade histórica e filosófica latino-americana antecipando, em certo sentido, muitos pontos das teorias dos atuais estudos "descoloniais".

5) No plano do debate artístico e cultural, antropofagia como operação cultural específica e como uma estratégia empregada em contextos políticos, econômicos e culturais assimétricos com fins de construir uma imaginação teórica da alteridade e da mestiçagem cultural mediante a apropriação criativa da contribuição do outro. A contribuição da "filosofia antropofágica" para tentar resolver as tensões resultantes do binômio nacional/cosmopolita ou América Latina/Europa, que tem sido "sintetizada" por várias nomenclaturas na crítica latino-americana: "modernidade periférica" (SARLO, 1988), "culturas híbridas" (CANCLINI, 2000) e "nacional estrangeiro" (MICELI, 2003).

O crítico e poeta brasileiro Haroldo de Campos (1992) considera que, no Brasil, com a antropofagia, tivemos um momento especialmente agudo no sentido da necessidade de pensar o nacional em relacionamento dialógico e dialético com o universal:

\begin{abstract}
A 'Antropofagia' oswaldiana é o pensamento da devoração crítica do legado cultural universal, elaborado não a partir da perspectiva submissa e reconciliada do "bom selvagem", mas segundo o ponto de vista desabusado do "mau selvagem", devorador de brancos, antropófago. Ela não envolve uma submissão (uma catequese), mas uma transculturação ${ }^{11}$; melhor ainda, uma "transvaloração": uma visão crítica da história como função negativa (no sentido de Nietzsche), capaz tanto de apropriação como de expropriação, desierarquização, desconstrução. Todo passado que nos é "outro" merece ser negado. Vale dizer: merece ser comido, devorado. Com esta especificação elucidativa: o canibal era um "polemista" (do grego pólemos = luta, combate), mas também um "antologista": só devorava os inimigos que
\end{abstract}

\footnotetext{
${ }^{11}$ Em seu célebre ensaio de 1940, Contrapunteo cubano del tabaco y el azúcar, o cubano Fernando Ortiz (1881-1969) cunhou o termo "transculturação" para designar a influência da cultura africana e de outros continentes na formação da cultura latino-americana.
}

\title{
GANPHLAC
}

Revista Eletrônica da ANPHLAC, ISSN 1679-1061, Nº. 17, p. 282-303, jul./dez. 2014. http://revista.anphlac.org.br/ 
considerava bravos, para deles tirar proteína e tutano para o robustecimento e a renovação de suas próprias forças naturais (CAMPOS, 1992, p. 235).

Segundo a argumentação de Haroldo, Oswald de Andrade representa uma maneira da consciência latino-americana de enfrentar o legado civilizacional e cultural europeu que aponta para um fato novo no relacionamento Europa/Latino-América. Caberia aos europeus ainda vinculados a razões eurocêntricas aprender a conviver e reconhecer a potência criativa da cultura dos "novos bárbaros que há muito, num contexto outro e alternativo, os estão devorando e fazendo deles carne de sua carne e osso de seu osso, que há muito os estão ressintetizando quimicamente por um irrefragável metabolismo da diferença" (CAMPOS, 1992, p. 254). Exemplos desses "bárbaros alexandrinos", gente que, além de dominar a cultura ocidental, tem incorporado em sua visão de mundo tradições culturais solenemente ignoradas pela inteligência eurocêntrica, poderiam ser: João Guimarães Rosa, Miguel Angel Astúrias, Octavio Paz, Borges, Lezama Lima, Mário de Andrade, Vicente Huidobro, todos eles, segundo o crítico brasileiro,

Grandes transculturadores, vândalos que há muito cruzaram as fronteiras e obrigam os "escritores logocêntricos", que se imaginavam usufrutuários privilegiados de uma orgulhosa koiné de mão única, prepararem-se para reconhecer e redevorar o tutano diferencial dos novos bárbaros da politópica e polifônica civilização planetária. (CAMPOS, 1992, p. 255)

Nessa linha interpretativa focada na inversão oswaldiana do modelo de trocas culturais, a antropofagia pode ser compreendida como operação cultural específica e como uma estratégia empregada em contextos políticos, econômicos e culturais assimétricos. João Cezar de Castro Rocha (2011) tenta compreender a antropofagia oswaldiana como uma promessa de formulação de uma imaginação teórica da alteridade, mediante a apropriação criativa da contribuição do outro. No mundo atual, caracterizado por um fluxo incessante de informação, aliado a uma vertiginosa pluralidade de meios de comunicação, talvez não haja "tarefa mais importante que o desenvolvimento de uma imaginação teórica capaz de processar dados oriundos de múltiplas circunstâncias e contextos” (ROCHA, 2011, p. 648). Urge, na visão de Castro

\section{GANPHLAC}

Revista Eletrônica da ANPHLAC, ISSN 1679-1061, Nº. 17, p. 282-303, jul./dez. 2014. http://revista.anphlac.org.br/ 
Rocha, a tarefa de desnacionalizar (ou "desbrasilizar") e mesmo "desoswaldianizar" a antropofagia, ou seja, reconhecer seu potencial reflexivo mais amplo, de visão de mundo. A filosofia de Oswald implica o entendimento da antropofagia como uma definição metafórica da apropriação da alteridade, um desafio de compor uma história alternativa da humanidade e uma contribuição para a formulação de uma subjetividade crítica que sustente uma nova utopia social.

\section{Referências documentais e bibliográficas:}

ABRAMSON, Pierre-Luc. Las utopías sociales en América Latina en el siglo XIX. México: FGE, 1999.

ADELINE, Yves-Marie. Abregé des definitions polithiques. Paris: Ellipses, 2013.

ADES, Dawn. Arte na América Latina: a era moderna - 1820-1980. São Paulo: Cosac \& Naif, 1997.

AMARAL, Aracy. Tarsila: sua obra e seu tempo. São Paulo: Ed. 34; EDUSO, 2003.

ANDRADE, Oswald de. A utopia antropofágica. São Paulo: Globo, 1990.

Serafim Ponte Grande. São Paulo: Globo, 2004.

ANSALDI, Waldo; GIORDANO, Verónica. América Latina: la construcción del orden: de la colonia a la disolución de la dominación oligárquica. Buenos Aires: Ariel, 2012.

BELluZZO, Ana Maria de Moraes (Org.). Modernidade: vanguardas artísticas na América Latina. São Paulo: UNESP, 1990.

BORON, Atílio. O socialismo no século 21: há vida após o neoliberalismo? São Paulo: Expressão Popular, 2010.

CAMPOS, Haroldo. Metalinguagem \& outras metas. São Paulo: Perspectiva, 1992.

\section{GANPHLAC}

Revista Eletrônica da ANPHLAC, ISSN 1679-1061, Nº. 17, p. 282-303, jul./dez. 2014.

http://revista.anphlac.org.br/ 
CANCLINI, Néstor García. Culturas híbridas: estratégias para entrar e sair da modernidade. São Paulo: EDUSP, 2000.

CARPENTIER, Alejo. Visão da América. São Paulo: Martins, 2006.

CASTRO-GÓMEZ, Santiago (Ed.). El giro decolonial: reflexiones para una diversidad epistémica más allá del capitalismo global. Bogotá: Siglo del Hombre, 2007.

CLAEYS, Gregory. Utopia: a história de uma ideia. São Paulo: Edições SESC, 2013.

CLASTRES, Pierre. A sociedade contra o Estado. Rio de Janeiro: Francisco Alves, 1978.

DÁVAlos, Pablo (Org.). Pueblos indígenas, estado y democracia. Buenos Aires: CLACSO, 2005.

DE SOUSA SANTOS, Boaventura. Renovar la teoría crítica y reinventar la emancipación social. Buenos Aires: CLACSO, 2006.

DEVÉS-VALDÉS, Eduardo. Pensamiento periférico. Asia-África-América LatinaEurasia y algo más: una tesis interpretativa global. Santiago de Chile: IDEA-USACH, 2012.

DUSSEL, Enrique. Hacía una filosofía política crítica. Bilbao: Editorial Desclée, 2001.

FAUSTO, Carlos. Inimigos fiéis: história, guerra e xamanismo na Amazônia. São Paulo: EDUSP, 2001.

FERNÁNDEZ RETAMAR, Roberto. Todo Caliban. Buenos Aires: CLACSO, 2004.

------.- Calíbã diante da antropofagia. In: ROCHA, J. C. de Castro; RUFFINELLI, Jorge (Org.). Antropofagia hoje? Oswald de Andrade em cena. São Paulo: É Realizações, 2011, p. 321-330.

FONTES PIAZZA, Maria de Fátima. O iberoamericanismo em Terra de Sol. In: ENCONTRO INTERNACIONAL DA ANPHLAC, IX, 2010, Goiânia. Anais Eletrônicos do IX Encontro Internacional da ANPHLAC. Goiânia: ANPHLAC; UFG, 2010.

HENRIQUEZ UREÑA, Pedro. La Utopía de América. Caracas: Ayacucho, 1978.

HUIZINGA, Johan. Homo ludens: o jogo como elemento da cultura. São Paulo: Ed. Perspectiva, 2004.

\section{GANPHLAC}

Revista Eletrônica da ANPHLAC, ISSN 1679-1061, Nº. 17, p. 282-303, jul./dez. 2014.

http://revista.anphlac.org.br/ 
JACKSON, K. D. Novas receitas da cozinha canibal: o manifesto antropófago hoje. In: ROCHA, J. C. de Castro; RUFFINELLI, Jorge. (Org.). Antropofagia hoje? Oswald de Andrade em cena. São Paulo: É Realizações, 2011.

KROTZ, Esteban. Utopía. México: UAM, 1988.

LANDER, Edgardo (Org.). A colonialidade do saber: eurocentrismo e ciências sociais. Buenos Aires: CLACSO, 2005.

LÖWY, Michael. Redenção e utopia: o judaísmo libertário na Europa central - um estudo de afinidade eletiva. São Paulo: Companhia das Letras, 1989.

(Org.). O marxismo na América Latina: uma antologia de 1909 aos dias atuais. São Paulo: Editora Perseu Abramo, 1999.

MANUEL, Frank E.; MANUEL, Fritzie P. El pensamiento utópico en el mundo occidental. Madrid: Taurus Ediciones, 1984.

MARCUSE, Herbert. A grande recusa hoje. Petrópolis: Vozes, 1999.

MARIÁTEGUI, José Carlos. Por um socialismo indo-americano: ensaios escolhidos. Rio de Janeiro: UFRJ, 2005.

MATTELART, Armand. História da utopia planetária: da cidade profética à sociedade global. Porto Alegre: Sulina, 2002.

MICELI, Sérgio. Nacional estrangeiro: história social e cultural do modernismo artístico em São Paulo. São Paulo: Companhia das Letras, 2003.

MIGNOLO, Walter. Histórias locais/projetos globais. Belo Horizonte: UFMG, 2003.

----------. La colonialidad global: capitalismo y hegemonía epistémica. In: SALVATORE, R. Culturas imperiales: experiencia y representación en América, Asia y África. Rosario: Beatriz Viterbo Editora, 2005.

MORSE, Richard. A volta de McLuhanaíma: cinco estudos solenes e uma brincadeira séria. São Paulo: Companhia das Letras, 1990.

O multiverso da identidade latino-americana. In: BETHELL, Leslie (Org.). História da América Latina: a América Latina após 1930: ideias, cultura e sociedade. São Paulo: EDUSP, 2011. p. 19-160.

NUNES, Benedito. Oswald canibal. São Paulo: Perspectiva, 1986.

ONFRAY, Michel. A política do rebelde: tratado de resistência e insubmissão. Rio de Janeiro: Rocco, 2001.

\section{CANPHLAC}

Revista Eletrônica da ANPHLAC, ISSN 1679-1061, Nº. 17, p. 282-303, jul./dez. 2014.

http://revista.anphlac.org.br/ 
ORTIZ, Fernando. Contrapunteo cubano del tabaco y el azúcar. Barcelona: Ariel, 1973.

PIÑEIRO IÑIGUEZ, Carlos. Pensadores latino-americanos del siglo XX: ideas, utopía y destino. Buenos Aires: Siglo XXI Editora Iberoamericana, 2006.

PORTO-GONÇALVES, Carlos Walter. Geografías, movimientos sociales, nuevas territorialidades y sustentabilidad. México: Siglo XXI, 2001.

QUIJANO, Aníbal. Colonialidade do poder, eurocentrismo e América Latina. In: LANDER, Edgardo (Org.). A colonialidade do saber: eurocentrismo e ciências sociais. Buenos Aires: CLACSO, 2005. p. 227-277.

RAMA, Ángel. Literatura, cultura e sociedade na América Latina. Belo Horizonte: Editora UFMG, 2008.

REVISTA DE ANTROPOFAGIA (Reedição fac-similada da $1^{\mathrm{a}}$ e $2^{\mathrm{a}}$ "dentições” 19281929. Introdução de Augusto de Campos). São Paulo: Cia. Lithographica Ypiranga, 1975.

REYES, Alfonso. Notas sobre la inteligencia americana. In: Obras completas. Tomo IV. México: FCE, 1956, p. 82-90.

ROCHA, J. C. de Castro. Uma teoria da exportação? Ou: antropofagia como visão de mundo. In: ROCHA, J. C. de Castro; RUFFINELLI, Jorge (Orgs.). Antropofagia hoje? Oswald de Andrade em cena. São Paulo: É Realizações, 2011. p. 647-668.

ROCHA, J. C. de Castro; RUFFINELLI, Jorge (Orgs.). Antropofagia hoje? Oswald de Andrade em cena. São Paulo: É Realizações, 2011.

SARLO, Beatriz. Una modernidad periférica: Buenos Aires 1920 y 1930. Buenos Aires: Nueva Visión, 1988.

SCHWARTZ, Jorge. Vanguardas latino-americanas: polêmicas, manifestos e textos críticos. São Paulo: EDUSP, 2008.

Fervor das vanguardas: arte e literatura na América Latina. São Paulo:

Companhia das Letras, 2013.

SHOHAT, E; STAM, R. Crítica da imagem eurocêntrica. São Paulo: Cosac Naify, 2006.

SKIRIUS, John (Org.). El ensayo hispano-americano del siglo XX. México: FCE, 1997.

SUBIRATS, Eduardo. Surrealistas, canibais e outros bárbaros. In: ROCHA, J. C. de Castro; RUFFINELLI, Jorge (Orgs.). Antropofagia hoje? Oswald de Andrade em cena. São Paulo: É Realizações, 2011. p. 257-257.

\section{GANPHLAC}

Revista Eletrônica da ANPHLAC, ISSN 1679-1061, Nº. 17, p. 282-303, jul./dez. 2014. http://revista.anphlac.org.br/ 
VANEIGEM, Raoul. A arte de viver para as novas gerações. São Paulo: Conrad, 2002.

VIVEIROS DE CASTRO, Eduardo. A inconstância da alma selvagem e outros ensaios de antropologia. São Paulo: Cosac Naify, 2002.

Encontros. Rio de Janeiro: Azougue Editorial, 2007.

YUPI, Mario. Modernidad y pensamiento descolonizador. La Paz: IFEA, 2006.

\section{GANPHLAC}

Revista Eletrônica da ANPHLAC, ISSN 1679-1061, Nº 17, p. 282-303, jul./dez. 2014.

http://revista.anphlac.org.br/ 